\title{
PENERAPAN TEKNIK MENGKLARIFIKASI NILAI (VALUE CLARIFICATION TECHNIQUE) UNTUK MENINGKATKAN PEMAHAMAN BELAJAR SISWA PADA MATA PELAJARAN PENDIDIKAN AGAMA ISLAM
}

\author{
Martoni*, Andrizal**, Helbi Akbar*** \\ Universitas Islam Kuantan Singingi, Riau, Indonesia \\ Email: *Martoni_toni@yahoo.com, **andrizal01@gmail.com, ${ }^{* * * H e l b i a k b a r @ u n i k s . a c . i d ~}$
}

\begin{abstract}
The subject of Islamic Education is a subject that focuses on the affective domain or attitude which consists of a vehicle for planting values, morals, and standard norms such as social sense, nationalism, and even a belief system. From the results of interviewing researchers with one of the PAI teachers, it was found that there were several problems in learning Islamic Religious Education including: Students had difficulty understanding Islamic Education subject matter, especially on material, imitating the attitude of Prophet As, Prophet Musa and Prophet Isa. Students also feel bored and bored in learning so that students do not interpret the learning process. The data in this study were obtained from observation, interviews, tests and documentation, with 8 students consisting of 3 men and 5 women. The results of the research on the implementation of the value clarification technique were proven to be able to improve the learning comprehension of fifth grade students in PAI subjects at SD N 003 Lubuk Kebun Logas Tanah Darat District. This can be seen from the results of the Pre-Cycle test of only 25\%, Cycle I rose to $41.7 \%$, Cycle II rose to $75 \%$ and Cycle III had reached $87.5 \%$ in PAI subjects at SD N 003 Lubuk Kebun Logas Tanah District Land.
\end{abstract}

Keywords: Value Clarification Techniques; Learning Understanding.

\begin{abstract}
Abstrak: Mata pelajaran Pendidikan Agama Islam merupakan mata pelajaran yang menitik beratkan pada ranah afektif atau sikap yang terdiri dari wahana penanaman nilai, moral, dan norma-norma baku seperti rasa sosial, nasionalisme, bahkan sistem keyakinan. Dari hasil wawancara peneliti dengan salah satu guru PAI ternyata, ditemukan beberapa masalah dalam pembelajaran Pendidikan Agama Islam diantaranya: Siswa mengalami kesulitan dalam memahami materi pelajaran Pendidikan Agama Islam khususnya pada materi meneladani sikap Nabi Ayub as, Nabi Musa as dan Nabi Isa as. Siswa juga merasa jenuh dan bosan dalam pembelajaran sehingga siswa kurang memaknai proses pembelajaran. Data dalam penelitian ini diperoleh dari observasi, wawancara, tes dan dokumentasi, dengan jumlah siswa 8 orang yang terdiri dari 3 orang laki-laki dan 5 orang perempuan. Hasil penelitian penerapan teknik mengklarifikasi nilai (value clarification technique) terbukti dapat meningkatkan pemahaman belajar siswa kelas V pada mata pelajaran PAI di SD N 003 Lubuk Kebun Kecamatan Logas Tanah Darat. Hal ini dapat dilihat dari hasil tes Pra Siklus hanya 25\%, Siklus I naik menjadi $41,7 \%$, Siklus II naik menjadi $75 \%$ dan Siklus III sudah mencapai 87,5\% dalam mata pelajaran PAI di SD N 003 Lubuk Kebun Kecamatan Logas Tanah Darat.
\end{abstract}

Kata Kunci: Teknik Mengklarifikasi Nilai; Pemahaman Belajar.

\section{PENDAHULUAN}

Pendidikan nasional berfungsi mengembangkan kemampuan dan membentuk watak serta peradaban bangsa yang bermartabat dalam rangka mencerdaskan kehidupan bangsa, bertujuan untuk berkembangnya potensi peserta didik agar menjadi manusia yang beriman dan bertakwa kepada Tuhan Yang Maha Esa, berakhlak mulia, sehat, berilmu, cakap, kreatif, mandiri dan menjadi warga negara yang demokratis dan bertanggung jawab (Citra Umbara, 2003: 32). 
Untuk mewujudkan tujuan pendidikan nasional diatas pendidikan agama Islam ikut berperan. Pendidikan Islam merupakan pendidikan manusia seutuhnya, akal dan keterampilan dengan tujuan menyiapkan manusia untuk menjalani hidup dengan baik (Qodri Azizi, 1995: 5). Namun hal itu tidak berjalan lurus, karena pendidikan Islam dipengaruhi oleh arus globalisasi yang terjadi saat ini. Globalisasi merupakan ancaman besar bagi pendidikan Islam untuk mempertahankan nilai-nilai agama yang murni. Selain itu, tantangan moral era globalisasi banyak membawa dampak negatif generasi muda sekarang, banyak generasi muda sudah terpengaruh dengan pergaulan yang global yang mengakibatkan banyaknya prilaku yang tidak sesuai dengan nilai agama.

Untuk menjawab tantangan tersebut perlu dilakukan sebuah pembaharuan dalam dunia pendidikan Islam, pembaharuan yang dilakukan menuntut agar pendidikan Islam semakin mengoptimalkan fungsi dari komponen-komponen dalam pendidikan Islam. Jika komponenkomponen dalam pendidikan Islam dapat berfungsi dengan baik, maka pencapaian tujuan pendidikan Islamakan semakin optimal (Hasbullah, 2011: 8). Selain itu untuk mencapai tujuan pendidikan Islam tentu dilakukaan dengan proses pembelajaran. Pembelajaran adalah proses interaksi antara peserta didik dengan pendidik dan sumber belajar pada suatu lingkungan belajar (Ramayulis, 2002: 38-41).

Dilihat sudut manajemen pembelajaran guru memegang peranan yang sangat penting. Sebagai komponen yang bertanggung jawab secara langsung terhadap perkembangan belajar siswa, guru harus mampu melakukan suatu pembaharuan secara berkala sesuai dengan tujuan pendidikan. Guru perlu melakukan pembaharuan terutama pada proses pembelajaran agar tujuan pendidikan dapat tercapai secara optimal. Pembaharuan yang dapat dilakukan guru khususnya guru pendidikan agama Islam yaitu dengan menerapkan pembelajaran yang mampu menanamkan nilai-nilai dari agama Islam (Habullaah, 2011: 19).

Selain itu guru harus dapat menerapkan pembelajaran yang efektif di sekolah agar peserta didik memiliki pemahaman tentang apa yang mereka pelajari selama proses pembelajaran dalam pendidikan agama Islam. Pemahaman belajar pendidikan Islam merupakan kemampuan seseorang untuk mempertahankan sesuatu yang dianggap benar, membedakan mana yang termasuk perbuatan baik dan buruk, memberikan contoh yang baik kepada sesama, dapat menerangkan sesuatu hal yang dapat dipahami dan lain sebagainya. Apabila seseorang telah memahami ajaran agama tersebut, meyakini dan mengamalkan semua perintah dan larangan dari ajaran agama tersebut, maka keyakinannya yang telah menjadi bagian integral dari kepribadiannya itulah yang akan mengawasi segala perbuatannya baik lahir maupun batin.

Namun pada kenyataannya, berdasarkan hasil wawancara dan pengamatan dengan salah satu guru Pendidikan Agama Islam ternyata ditemukan beberapa masalah dalam pembelajaran Pendidikan Agama Islam diantaranya:

1. Siswa mengalami kesulitan dalam memahami materi pelajaran PAI khususnya pada materi meneladani sikap Nabi Ayub as, Nabi Musa as dan Nabi Isa as.

2. Disekolah tersebut siswa kurang menaruh perhatian dalam proses pembelajaran Pendidikan Agama Islam.

3. Siswa kurang semangat mengerjakan tugas-tugas belajarnya, siswa kurang aktif dan tidak berani mengemukakan pendapatnya dalam pembelajaran.

4. Siswa juga merasa jenuh dan bosan dalam pembelajaran sehingga siswa kurang memaknai proses pembelajaran.

5. Teknik pembelajaran yang digunakan guru PAI tidak bervariasi.

6. Guru juga belum menggunakan media dalam proses pembelajarannya

Berdasarkan analisa dari pengamatan dan wawancara penulis permasalahan tersebut disebabkan karena gaya mengajar guru yang kurang menarik, media dan sumber belajar yang digunakan monoton atau tidak memperkaya dengan sumber-sumber lain. Selain itu konsep pembelajaran PAI sering kali tidak dibelajarkan seutuhnya yaitu tidak mencakup aspek kognitif, afektif dan psikomotor secara utuh.

Salah satu alternatif utuk mengatasi permasalahan diatas adalah dengan menerapkan Tekhnik Mengklarifikasi Nilai dalam pembelajaran PAI. Teknik mengklasifikasi nilai (value clarification technique) atau sering disingkat VCT dapat diartikan sebagai teknik pengajaran untuk membantu siswa dalam mencari dan menentukan status nilai yang dianggap baik dalam menghadapi 
suatu persoalan melalui proses menganalisis nilai yang sudah ada dan tertanam dalam diri siswa (Wina Sanjaya, 2017: 283). VCT merupakan pengajaran untuk membentuk siswa dalam mencari dan menentukan suatu nilai yang dianggap baik dalam menghadapi suatu persoalan melalui proses menganalisis nilai yang sudah ada dan tertanam dalam diri siswa (Wina Sanjaya, 2010: 34).

\section{Teknik Mengklarifikasi Nilai (Value Clarification Teqnique)}

Dalam mata pelajaran PAI, pembelajaran erat kaitannya dengan ranah afektif. Oleh karena itu, dibutuhkan suatu teknik pembelajaran afektif yang erat kaitannya dengan nilai yang sulit diukur tersebut. Amri dan Ahmadi mengemukakan pengertian pembelajaran afektif sebagai pembelajaran yang tidak hanya bertujuan untuk mencapai pendidikan kognitif saja, tetapi juga bertujuan untuk mencapai dimensi yang lainnya yaitu sikap dan keterampilan afektif (Amri, Sofan dan Iif Khoiru Ahmadi, 2016:208). Salah satu teknik pembelajaran afektif pada pembelajaran adalah dengan menerapkan teknik mengklarifikasi nilai (Value Clarification Technique) dalam proses pembelajarannya.

Istilah klarifikasi secara bahasa berarti penjernihan atau penjelasan. Klarifikasi dapat didefenisikan suatu tindakan untuk menjelaskan sesuatu secara lebih jelas dan mudah dipahami yang berguna untuk memebaskan sesuatu dai ambiguitas. Secara umum, pengertian klarifikasi adalah sebuah cara atau sikap untuk memberi penjelasan tentang hal yang sebenarnya, dari informasi yang sedikit keliru dan sudah terlanjur beredar.

Teknik mengklarifikasi nilai merupakan teknik menanamkan nilai (values) yang merujuk pada pendekatan nilai dengan cara sedemikian rupa sehingga peserta didik memperoleh kejelasan/ kemantapan nilai. Menurut Masnur muslih teknik mengklarifikasi nilai memberikan penekanan pada usaha membantu siswa dalam mengkaji perasaan dan perbuatannya sendiri, untuk meningkatkan kesadaran mereka tentang nilai- nilai mereka sendiri (Masnur Muslih, 2006: 116). Djahiri dalam Allamri dan Ichas mengemukakan bahwa VCT merupakan sebuah cara menanamkan dan mengungkapkan nilai-nilai tertentu dari siswa (Al-lamri, S. Ichas Hamid dan Tuti Istianti Ichas, 2015: 87). Menurut Bahar VCT merupakan suatu teknik pengklarifikasian sikap yang sesuai dengan tuntutan perkembangan pembelajaran masa sekarang. Sanjaya juga berpendapat bahwa teknik mengklarifikasi nilai (value clarification technique) dapat membantu siswa mencari dan menentukan suatu nilai yang dianggapnya baik dalam menghadapi suatu persoalan melalui proses menganalisis nilai yang sudah ada dan tertanam dalam diri siswa. Pada pembelajaran value clarification technique (VCT) ini guru mengharapkan siswa teribat aktif dalam mengembangkan pemahaman dan pengenalannya terhadap nilai-nilai pribadi, mengambil keputusan, dan bertindak sesuai dengan keputusan yang diambil, mendorong siswa dengan pertanyaan-pertanyaan untuk mengembangkan keterampilan siswa dalam proses menilai, menggali dan mempertegas nilai-nilai yang dimiliki siswa. VCT menekankan bagaimana sebenarnya seseorang membangun nilai yang menurut anggapannya baik, yang pada gilirannya nilai-nilai tersebut akan mewarnai perilakunya dalam kehidupan seharihari di masyarakat (Wina Sanjaya, 2010: 283).

Berdasarkan uraian di atas, dapat disimpulkan bahwa value clarification technique (VCT) adalah suatu metode pembelajaran yang untuk membantu siswa mengembangkan pemahaman suatu nilai yang dianggap baik dalam menghadapi suatu persoalan melalui proses menganalisis nilai yang sudah ada dan tertanam dalam diri siswa.

Tujuan menggunakan teknik mengklarifikasi nilai (value clarification technique) dalam pembelajaran menurut yaitu: (1) mengetahui dan mengukur tingkat kesadaran siswa tentang suatu nilai; (2) menanamkan kesadaran siswa tentang nilai-nilai yang dimiliki; (3) menanamkan nilai-nilai tertentu kepada siswa melalui cara yang rasional (logis) dan diterima siswa; (4) melatih siswa dalam menerima dan menilai nilai dirinya dan posisi nilai orang lain.

Jarolimek mengklasifikasikan langkah-langkah pelaksanaan teknik mengklarifikasi nilai (value clarification technique) ke dalam 7 tahap yang dibagi menjadi 3 tingkat. Setiap tahap dijelaskan sebagai berikut:

1. Kebebasan Memilih, yang terdiri dari 3 tahap pembelajaran yaitu:

a. Memilih secara bebas, artinya kesempatan untuk menentukan pilihan yang menurutnya baik karena nilai yang dipaksakan tidak akan menjadi miliknya secara penuh;

b. Memilih dari beberapa alternatif, artinya untuk menentukan pilihan dari beberapa alternatif pilihan secara bebas; serta 
c. Memilih setelah dilakukan analisis pertimbangan konsekuensi yang akan timbul sebagai akibat pilihannya.

2. Menghargai, terdiri dari 2 tahap pembelajaran, yaitu:

a. Adanya perasaan senang dan bangga dengan nilai yang menjadi pilihannya, sehingga nilai tersebut akan menjadi bagian dari dirinya;

b. Menegaskan nilai yang sudah menjadi bagian integral dalam dirinya di depan umum, artinya jika kita menganggap nilai itu suatu pilihan, maka kita akan berani dengan penuh kesadaran untuk menunjukkannya di depan orang lain.

3. Berbuat, terdapat 2 tahap pembelajaran, yaitu:

a. Kemauan dan kemampuan untuk mencoba melaksanakannya;

b. Mengulangi perilaku sesuai dengan nilai pilihannya, artinya nilai yang menjadi pilihan itu harus tercermin dalam kehidupannya sehari-hari (Wina Sanjaya, 2010:284).

Jika dilihat dari tahap-tahap pelaksanaannya, pembelajaran VCT sebetulnya menekankan bagaimana seseorang membangun nilai yang dianggapnya baik untuk diaplikasikan dalam kehidupan sehari-hari. Dalam prosespembelajarannya, VCT dapat dikembangkan melalui proses dialog.

Menurut Wina Sanjaya, 2010: 284, beberapa hal yang harus diperhatikan guru ketika melakukan dialog pada proses pembelajaran menggunakan teknik mengklarifikasi nilai (value clarification technique), yaitu:

1. Hindari penyampaian pesan melalui proses pemberian nasihat atau pesan-pesan moral yang menurut guru dianggap baik.

2. Jangan memaksa siswa memberi respon tertentu apabila siswa memang tidak menghendakinya.

3. Usahakan dialog dilaksanakan secara bebas dan terbuka, sehingga siswa akan mengungkapkan perasaannya secara jujur dan apa adanya.

4. Dialog dilaksanakan kepada individu, bukan kepada kelompok kelas.

5. Hindari respon yang dapat menyebabkan siswa terpojok.

6. Tidak mendesak siswa pada pendirian tertentu.

7. Jangan mengorek alasan siswa lebih dalam.

\section{Pemahaman}

Pemahaman merupakan proses berpikir dan belajar. Dikatakan demikian karena untuk menuju ke arah pemahaman perlu diikuti dengan belajar dan berpikir. Pemahaman merupakan proses, perbuatan dan cara memahami (W.J.S Purwadarminta, 1991: 636).

Pemahaman adalah tingkatan kemampuan yang mengharapkan seseorang mampu memahami arti atau konsep, situasi serta fakta yang diketahuinya. Dalam hal ini ia tidak hanya hapal secara verbalitas, tetapi memahami konsep dari masalah atau fakta yang ditanyakan, maka operasionalnya dapat membedakan, mengubah, mempersiapkan, menyajikan, mengatur, menginterpretasikan, menjelaskan, mendemonstrasikan, memberi contoh, memperkirakan, menentukan, dan mengambil keputusan (Nalim Purwanto, 1997: 44).

Di dalam ranah kognitif menunjukkan tingkatan-tingkatan kemampuan yang dicapai dari yang terendah sampai yang tertinggi. Dapat dikatakan bahwa pemahaman tingkatannya lebih tinggi dari sekedar pengetahuan. Definisi pemahaman menurut Anas Sudijono adalah: "kemampuan seseorang untuk mengerti atau memahami sesuatu setelah sesuatu itu diketahui dan diingat. Dengan kata lain, memahami adalah mengetahui tentang sesuatu dan dapat melihatnya dari berbagai segi. Pemahaman merupakan jenjang kemampuan berpikir yang setingkat lebih tinggi dari pengetahuan" (Anas Sudijono, 1996: 50).

Menurut Benyamin S. Bloom, "pemahaman merupakan kemampuan untuk memahami apa yang sedang dikomunikasikan dan mampu mengimplementasikan ide tanpa haus mengaitkannya dengan ide lain, dan juga tanpa harus melihat ide tersebut secara mendalam" (Dede Rosdaya, 2004: 73).

Indikator pemahaman konsep menurut Benyamin S. Bloom sebagai berikut:

1. Penerjemahan (translation), menterjemahkan konsepsi abstrak menjadi suatu model.

2. Penafsiran (Interpretation), yaitu kemampuan untuk mengenal dan memahami ide utama suatu komunikasi. 
3. Ekstrapolasi (extrapolation), yaitu menyimpulkan dari sesuatu yang telah diketahui (Nana Sudjana, 2009:24).

Pemahaman sebagai bagian dari tipe hasil belajar yang merupakan objek penilaian guru karena berkaitan dengan kemampuan para siswa dalam menguasai isi bahan pelajaran. Adapun faktor-faktor yang mempengaruhi pemahaman atau keberhasilan belajar siswa adalah sebagai berikut:

a. Faktor internal (dari diri sendiri)

1) Faktor jasmaniah (fisiologi) meliputi: keadaan panca indera yang sehat tidak mengalami cacat (gangguan) tubuh, sakit atau perkembangan yang tidak sempurna.

2) Faktor psikologis, meliputi: keintelektualan (kecerdasan), minat, bakat, dan potensi prestasi yang di miliki.

3) Faktor pematangan fisik atau psikis.

b. Faktor eksternal (dari luar diri)

1) Faktor social meliputi: lingkungan keluarga, lingkungan sekolah, lingkungan kelompok, dan lingkungan masyarakat.

2) Faktor budaya meliputi: adat istiadat, ilmu pengetahuan, teknologi, dan kesenian.

3) Faktor lingkungan fisik meliputi: fasilitas rumah dan sekolah.

4) Faktor lingkungan spiritual (keagamaan).

Dari sekian banyak faktor diatas maka untuk mencapai hasil belajar siswa pada tingkat pemahaman, salah satunya dapat dipengaruhi oleh faktor guru. Dimana guru harus mampu merancang pelaksanaan pembelajaran, yaitu menyusun perencanaan, proses pelaksanaan pembelajaran, menentukan metode, strategi, media dan alat evaluasi. Untuk itu guru harus melakukan upaya-upaya dalam proses pembelajaran, bagaimana menentukan perencanaan, pelaksanaan dan evaluasi pembelajaran yang disesuaikan dengan kondisi siswa agar mencapai tingkat pemahaman yang optimal dalam memahami suatu materi yang diajarkan.

\section{HASIL DAN PEMBAHASAN}

Pada tahap pra siklus ini penyampaian materi dilakukan oleh guru dengan metode ceramah dan meminta siswa untuk memahami materi dan membuat kesimpulan tanpa menggunakan bantuan media, ternyata pemahaman siswa tidak seperti yang diharapkan. Hal ini terlihat dimana sebagian besar siswa tidak mampu mengerjakan tes yang diberikan oleh guru dengan benar dikarenakan guru belum menggunakan teknik pembelajaran yang bervariasi dalam proses pembelajaran PAI, hal ini dapat kita lihat dengan seksama seperti hasil tabel berikut ini:

Tabel. 1. Pra Siklus Pemahaman Belajar Siswa Pada Mata Pelajaran PAI Sebelum Penerapan Teknik Mengklarifikasi Nilai

\begin{tabular}{|c|l|c|c||}
\hline No & \multicolumn{1}{|c|}{ Indikator Pemahaman Belajar Siswa } & Frek & \% \\
\hline \hline 1 & $\begin{array}{l}\text { Translation, adalah siswa mampu mendefinisikan ulang } \\
\text { tentang materi yang diajarkan }\end{array}$ & 3 & 37,5 \\
\hline 2 & $\begin{array}{l}\text { Interpretation, adalah siswa mampu memberikan penjelasan } \\
\text { terhadap materi pelajaran dalam kehidupan sehari-hari. }\end{array}$ & 1 & 12,5 \\
\hline 3 & $\begin{array}{l}\text { Ekstrapolation, adalah siswa mampu memberi kesimpulan } \\
\text { atas konsep pembelajaran dengan bahasa sendiri. }\end{array}$ & 2 & 25 \\
\hline \hline \multicolumn{2}{|c|}{ Rata-rata persentase pemahaman belajar siswa } & 25 \\
\hline
\end{tabular}

Dari hasil Pra Siklus diatas dapat dilihat hanya 25 \% saja siswa yang memiliki pemahaman belajar yang baik, sementara siswa yang lainnya $75 \%$ pemahaman belajarnya sangat jauh dari apa yang diharapkan. Ternyata setelah diperhatikan secara seksama hal ini disebabkan karena penyampaian materi guru PAI kurang menarik minat siswa karena tidak ada variasi teknik pembelajaran dan media dalam proses pembelajaran yang digunakan guru, guru kurang mengontrol siswa yang tidak serius dalam pembelajaran PAI, siswa kurang mampu mengungkapkan pendapat atau menjawab pertanyaan dikarenakan tidak menariknya teknik pembelajaran yang digunakan guru, pengelolaan kelas yang kurang efektif sehingga siswa tidak memperhatikan penjelasan yang diberikan guru. 
Pada siklus I ini peneliti menerapkan secara langsung teknik pembelajaran baru yakni teknik mengklarifikasi nilai untuk meningkatkan pemahaman belajar siswa kelas V pada mata pelajaran PAI di SD N 003 Lubuk Kebun Kecamatan Logas Tanah Darat. Agar pembelajaran sesuai dan subjektif peneliti menggunakan RPP sebagai acuan pembelajaran PAI dan mengadakan beberap persiapan yang di anggap perlu. Kegiatan pada siklus I ini dapat kita lihat kegiatan pembelajaran berikut:

Ternyata pada siklus pertama ini dapat dilihat pemahaman belajar siswa sudah mulai meningkat dari pada sebelum diterapkannya teknik mengklarifikasi nilai (value clarification technique) seperti pada tabel berikut:

Tabel. 2. Siklus I Pemahaman Belajar Siswa Pada Mata Pelajatan PAI Setelah Penerapan Teknik Mengklarifikasi Nilai

\begin{tabular}{|l|l|c|c|}
\hline No & \multicolumn{1}{|c|}{ Indikator Pemahaman Belajar Siswa } & Frek & \% \\
\hline \hline 1 & $\begin{array}{l}\text { Translation, adalah siswa mampu mendefinisikan ulang tentang } \\
\text { materi yang diajarkan }\end{array}$ & 7 & 87,5 \\
\hline 2 & $\begin{array}{l}\text { Interpretation, adalah siswa mampu memberikan penjelasan } \\
\text { terhadap materi pelajaran dalam kehidupan sehari-hari. }\end{array}$ & 3 & 37,5 \\
\hline 3 & $\begin{array}{l}\text { Ekstrapolation, adalah siswa mampu memberi kesimpulan atas } \\
\text { konsep pembelajaran dengan bahasa sendiri. }\end{array}$ & 4 & 50 \\
\hline \multicolumn{1}{|c|}{ Rata-rata persentase pemahaman belajar siswa } & 58,3 \\
\hline
\end{tabular}

Dari hasil evaluasi yang diadakan pada tanggal 21 april 2017 ini ternyata 58,3\% siswa sudah mempunyai pemahaman belajar yang cukup memadai di kelas V SD N 003 Lubuk Kebun, sementara itu yang pemahaman belajarnya yang masih rendah hanya tinggal $41,7 \%$ saja, disini terlihat pemahaman belajar siswa telah mengalami peningkatan.

Hal ini terjadi dapat dimaklumi karena teknik mengklarifikasi nilai (value clarification technique) baru diterapkan dalam proses pembelajaran, sehingga siswa terkesan masih kurang memahami namun demikian antusiasme siswa sudah mulai tampak, secara perlahan siwa yang selama ini terkesan pasif dalam pembelajaran sudah mulai berani untuk menentukan pilihan yang menurutnya baik dengan sendirinya pemahaman belajar siswa kelas $\mathrm{V}$ sudah mulai mengalami peningkatan.

Dari hasil refleksi dilapangan, ternyata dalam tercapainya peningkatan pemahaman belajar siswa ada beberapa kendala yang dijumpai yakni siswa masih belum terbiasa dengan teknik mengklarifikasi nilai yang baru pertama kali diterapkan dalam pembelajaran PAI, siswa mulai terlihat antusias namun masih ragu-ragu dalam menentukan nilai yang dianggapnya baik, dan siswa masih belum mampu menerjemahkan dengan benar gambar yang diberikan.

Dengan melihat pelaksanaan siklus I diatas, maka peneliti mengadakan refleksi kembali untuk mengevaluasi kegagalan pada siklus I dan kembali menerapkan secara benar teknik mengklarifikasi nilai (value clarification technique) dalam proses pembelajaran untuk meningkatkan pemahaman belajar siswa pada siklus II untuk menyempurnakan hasil-hasil pada siklus I dengan harapan akan tercapai pemahaman belajar siswa kelas $\mathrm{V}$ delam mata pelajaran PAI yang lebih maksimal. Untuk lebih jelasnya bagaimana peningkatan pemahaman belajar siswa dapat kita lihat hasilnya pada tabel berikut ini:

Tabel. 3. Siklus II Pemahaman Belajar Siswa Pada Mata Pelajatan PAI Setelah Penerapan Teknik Mengklarifikasi Nilai

\begin{tabular}{|l|l|c||c||}
\hline No & \multicolumn{1}{|c|}{ Indikator Pemahaman Belajar Siswa } & Frek & \% \\
\hline \hline 1 & $\begin{array}{l}\text { Translation, adalah siswa mampu mendefinisikan ulang tentang } \\
\text { materi yang diajarkan }\end{array}$ & 7 & 87,5 \\
\hline \hline 2 & $\begin{array}{l}\text { Interpretation, adalah siswa mampu memberikan penjelasan } \\
\text { terhadap materi pelajaran dalam kehidupan sehari-hari. }\end{array}$ & 6 & 75 \\
\hline 3 & $\begin{array}{l}\text { Ekstrapolation, adalah siswa mampu memberi kesimpulan atas } \\
\text { konsep pembelajaran dengan bahasa sendiri. }\end{array}$ & 5 & 62,5 \\
\hline \hline \multicolumn{1}{|c||}{ Rata-rata persentase pemahaman belajar siswa } & 75 \\
\hline
\end{tabular}

Dari hasil evaluasi yang diadakan pada hari Selasa 25 April 2017 ini ternyata 75\% siswa sudah mempunyai pemahaman belajar yang baik dikelas V SD N 003 Lubuk Kebun Kecamatan Logas 
Tanah Darat, sementara itu pemahaman belajar siswa yang masih tergolong rendah hanya tinggal $25 \%$, disini terlihat jelas peningkatan pemahaman belajar siswa dengan diterapkanya teknik mengklarifikasi nilai (value clarification technique) pada mata pelajaran PAI.

Dari hasil refleksi pada siklus II ini, ternyata masih ada beberapa kendala yang dijumpai dalam peningkatan pemahaman belajar siswa kelas V pada mata pelajaran PAI di SD N 003 Lubuk Kebun Kecamatan Logas Tanah Darat Kabupaten Kuantan Singingi sebagai berikut : siswa masih dalam tahap pembiasaan dengan teknik mengklarifikasi nilai yang baru kali kedua diterapkan dalam pembelajaran, dan sebagian siswa belum berani tampil didepan kelas untuk menegaskan nilai yang menjadi pilihannya.

Peneliti kembali mengadakan refleksi untuk mengevaluasi kegagalan pada siklus II dan kembali menerapkan teknik mengklarifikasi nilai (value clarification technique) dalam proses pembelajaran pada siklus III untuk lebih menyempurnakan pemahaman belajar siswa yang dicapai pada siklus sebelumnya.

Tabel. 4. Siklus III Pemahaman Belajar Siswa Pada Mata Pelajaran PAI Setelah Penerapan Teknik Mengklarifikasi Nilai

\begin{tabular}{|c|l|c|c||}
\hline No & \multicolumn{1}{|c|}{ Indikator Pemahaman Belajar Siswa } & Frek & \% \\
\hline 1 & $\begin{array}{l}\text { Translation, adalah siswa mampu mendefinisikan ulang tentang } \\
\text { materi yang diajarkan }\end{array}$ & 8 & 100 \\
\hline 2 & $\begin{array}{l}\text { Interpretation, adalah siswa mampu memberikan penjelasan } \\
\text { terhadap materi pelajaran dalam kehidupan sehari-hari. }\end{array}$ & 7 & 87,5 \\
\hline 3 & $\begin{array}{l}\text { Ekstrapolation, adalah siswa mampu memberi kesimpulan atas } \\
\text { konsep pembelajaran dengan bahasa sendiri. }\end{array}$ & 6 & 75 \\
\hline \hline \multicolumn{2}{|c|}{ Rata-rata persentase pemahaman belajar siswa } & 87,5 \\
\hline
\end{tabular}

Dari hasil evaluasi yang diadakan pada tanggal 28 April 2017 ini ternyata sudah 87,5 \% siswa sudah mampu dan sudah mempunyai pemahaman belajar yang baik sementara pemahaman belajar yang rendah hanya tinggal $12,5 \%$ siswa saja. Secara keseluruhan siswa sudah mempunyai pemahaman belajar yang memadai dikelas V SD N 003 Lubuk Kebun Kecamatan Logas Tanah Darat, sementara itu siswa yang memiliki pemahaman belajar yang belum memadai hanya tinggal sebagaian kecil saja, disini terlihat telah terbukti penerapan teknik mengklarifikasi nilai (value clarification technique) yang diterapkan disekolah ini untuk meningkatkan pemahaman belajar siswa cukup berhasil. Tentu hal ini tidak berhenti disini saja tetapi diharapkan teknik pembelajaran ini akan lebih mampu lagi membuat siswa meningkatkan pemahaman belajar mata pelajaran PAI sehingga nilai-nilai yang dipelajari akan dapat mendarah daging dan diterapkan dalam kehidupan sehari-hari.

Setelah diadakan tes dan observasi langsung kedalam kelas dengan 4 siklus masing-masing tanggal 18 sampai 28 April 2013 disaat proses pembelajaran PAI berlangsung dengan penerapan teknik mengklarifikasi nilai (value clarification technique) pada siswa kelas V SD N 003 Lubuk Kebun Kecamatan Logas Tanah Darat dapat dilihat hasilnya dengan memperhatikan rekapitulasi data berikut ini:

Tabel. 5. Rekapitulasi Hasil Obsevasi Penerapan Teknik Mengklarifikasi Nilai Dalam Pembelajaran PAI

\begin{tabular}{|c||c|c|c|c|c|c|c||}
\hline \multicolumn{2}{|c|}{$\begin{array}{c}\text { Sebelum } \\
\text { Pelaks. VCT }\end{array}$} & \multicolumn{2}{c|}{$\begin{array}{c}\text { Setelah Pelaks. } \\
\text { VCT }\end{array}$} & \multicolumn{2}{c||}{$\begin{array}{c}\text { Setelah Pelaks. } \\
\text { VCT }\end{array}$} & \multicolumn{2}{c|}{$\begin{array}{c}\text { Setelah Pelaks. } \\
\text { VCT }\end{array}$} \\
\hline Sdh & Blm & Sdh & Blm & Sdh & Blm & Sdh & Blm \\
\hline$\sqrt{ }$ & & $\sqrt{ }$ & & $\sqrt{ }$ & & $\sqrt{ }$ & \\
\hline \hline & $\sqrt{ }$ & $\sqrt{ }$ & & $\sqrt{ }$ & & $\sqrt{ }$ & \\
\hline \hline & $\sqrt{ }$ & $\sqrt{ }$ & & $\sqrt{ }$ & & $\sqrt{ }$ & \\
\hline \hline & $\sqrt{ }$ & & $\sqrt{ }$ & & $\sqrt{ }$ & $\sqrt{ }$ & \\
\hline & $\sqrt{ }$ & & $\sqrt{ }$ & $\sqrt{ }$ & & $\sqrt{ }$ & \\
\hline & $\sqrt{ }$ & $\sqrt{ }$ & & $\sqrt{ }$ & & $\sqrt{ }$ & \\
\hline
\end{tabular}




\begin{tabular}{|c||c|c|c|c|c|c|c|}
\hline & $\sqrt{ }$ & & $\sqrt{ }$ & $\sqrt{ }$ & & $\sqrt{ }$ & \\
\hline & $\sqrt{ }$ & $\sqrt{ }$ & & $\sqrt{ }$ & & $\sqrt{ }$ & \\
\hline 1 & 8 & 5 & 4 & 7 & 2 & 9 & 0 \\
\hline
\end{tabular}

Dari tabel 5 dapat dilihat bahwa pelaksanaan teknik mengklarifikasi nilai (value clarification technique) pada observasi pertama menunjukkan guru PAI belum melaksanakan teknik mengklarifikasi nilai (value clarification technique) dalam pembelajaran PAI pada siswa kelas V yaitu hanya mencapai 1 item saja, namun setelah observasi II dimana peneliti mulai melaksanakan teknik mengklarifikasi nilai (value clarification technique) hasilnya mulai mengalami peningkatan yaitu 5 item. Pada observasi ke III peneliti telah melaksanakan 7 item dan pada observasi ke IV teknik mengklarifikasi nilai (value clarification technique) telah secara sempurna dilaksanakan oleh peneliti dalam pembelajaran untuk meningkatkan pemahaman belajar siswa kelas V di SD N 003 Lubuk Kebun Kecamatan Logas Tanah Darat.

Tabel. 6. Rekapitulasi Hasil Test Pemahaman Belajar Siswa Dalam Mata Pelajaran PAI

\begin{tabular}{|c|c|c|c|c|c|c|c|}
\hline \multicolumn{2}{|c|}{ Pra Siklus } & \multicolumn{2}{|c|}{ Siklus I } & \multicolumn{2}{|c|}{ Siklus II } & \multicolumn{2}{|c|}{ Siklus III } \\
\hline Frek & $\%$ & Frek & $\%$ & Frek & $\%$ & Frek & $\%$ \\
\hline 3 & 37,5 & 7 & 87,5 & 7 & 87,5 & 8 & 100 \\
\hline 1 & 12,5 & 3 & 37,5 & 6 & 75 & 7 & 87,5 \\
\hline 2 & 25 & 4 & 50 & 5 & 62,5 & 6 & 75 \\
\hline $\begin{array}{l}\text { Rata- } \\
\text { Rata }\end{array}$ & 25 & $\begin{array}{l}\text { Rata- } \\
\text { Rata }\end{array}$ & 58,3 & $\begin{array}{l}\text { Rata- } \\
\text { Rata }\end{array}$ & 75 & $\begin{array}{l}\text { Rata- } \\
\text { Rata }\end{array}$ & 87,5 \\
\hline
\end{tabular}

Dari rekapitulasi tabel 6 bahwa hasil tes diatas dapat di analisa data penelitian bahwa pemahaman belajar siswa terhadap materi PAI yaitu dari hasil tes pra siklus (sebelum pelaksanaan teknik mengklarifikasi nilai) terlihat hanya $25 \%$ siswa saja yang memiliki pemahaman belajar PAI yang baik, sementara 75\% lainnya sangat jauh dari yang diharapkan, dari hasil tes siklus I ternyata 58,3\% siswa sudah memiliki pemahaman yang memadai dikelas V SD N 003 Lubuk Kebun Kecamatan Logas Tanah Darat sementara siswa yang pemahaman belajarnya masih tergolong rendah 41,7\%, disini terlihat pemahaman belajar siswa mulai meningkat secara perlahan, dari hasil tes pada siklus II ternyata sudah $75 \%$ siswa yang memiliki pemahaman belajar yang baik dikelas V SD N 003 Lubuk Kebun Kecamatan Logas Tanah Darat, sementara pemahaman belajar siswa yang masih rendah sebesar 25\%, disini terlihat pemahaman belajar siswa meningkat 16,7\%, dari hasil tes pada siklus II ternyata $87,5 \%$ siswa telah memiliki pemahaman belajar yang baik dalam pembelajaran PAI, sementara siswa yang belum mampu hanya tinggal 12,5\% saja. Berarti secara keseluruhan siswa sudah memiliki pemahaman belajar yang baik dikelas V SD N 003 Lubuk Kebun Kecamatan Logas Tanah Darat. Sementara itu siswa yang memiliki pemahaman belajar yang belum memadai hanya tinggal segelintir kecil saja.

Untuk Lebih Jelasnya peningkatan pemahaman belajar siswa dalam pembelajaran PAI dapat dilihat melalui grafik berikut ini:

Gambar 1. Peningkatan pemahaman belajar siswa dalam pembelajaran PAI

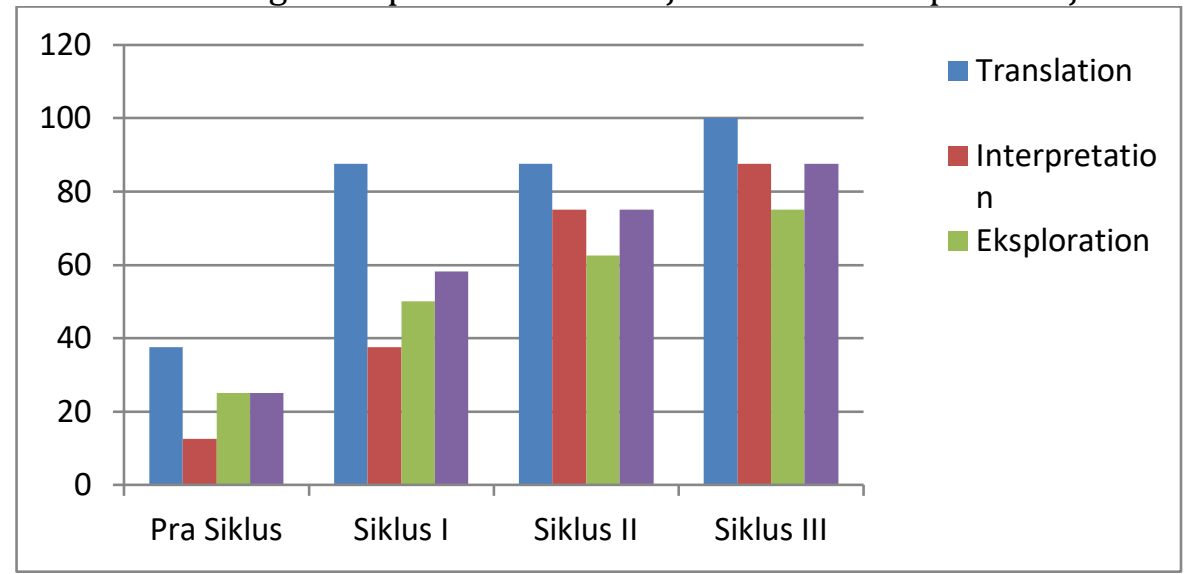


Keterangan grafik:

a. Warna biru menunjukkan indikator pemahaman item mendefenisikan tentang materi yang diajarkan

b. Warna Merah siswa mampu memberikan penjelasan terhadap materi pelajaran dalam kehidupan sehari-hari.

c. Warna hijau siswa mampu memberi kesimpulan atas konsep pembelajaran dengan bahasa sendiri.

d. Warna ungu menunjukkan rata-rata pemahaman belajar siswa.

\section{KESIMPULAN}

Dari uraian hasil penelitian dapat diambil kesimpulan bahwa penerapan teknik mengklarifikasi nilai (value clarification technique) terbukti dapat meningkatkan pemahaman belajar siswa kelas V pada mata pelajaran PAI di SD N 003 Lubuk Kebun Kecamatan Logas Tanah Darat. Hal ini dapat dilihat dari hasil tes Pra Siklus hanya $25 \%$ siswa saja yang memiliki pemahaman belajar PAI yang baik, Siklus I naik menjadi $41,7 \%$ siswa yang memiliki pemahaman belajar yang baik, Siklus II naik menjadi $75 \%$ siswa yang memiliki pemahaman belajar yang baik dan ternyata pada Siklus III siswa kelas $V$ yang memiliki pemahaman belajar yang baik sudah mencapai $87,5 \%$ dalam mata pelajaran PAI di SD N 003 Lubuk Kebun Kecamatan Logas Tanah Darat.

\section{DAFTAR PUSTAKA}

Anas, Sudijono. (1996). Pengantar Evaluasi Pendidikan. Jakarta: PT. Raja Grafindo Persada

Al-lamri, S. Ichas Hamid dan Tuti Istianti Ichas. (2015). Pengembangan Pendidikan Nilai dalam Pembelajaran Pengetahuan Sosial di Sekolah Dasar. Jakarta: Dirjen dikti

Amri, Sofan. Iif Khoiru Ahmadi. (2016). Proses Pembelajaran Kreatifdan InovatifDalam Kelas: Metode, Landasan Teoritis-Praktis dan Penerapannya. Jakarta: PT. Prestasi Pustakaraya

Citra Umbara. (2003). Undang-Undang Republik Indonesia No. 20 Tahun 2003 Tentang Sistem Pendidikan Nasional. Bandung.

Dede Rosyada. (2014). Paradigma Pendidikan Demokratis. Jakarta: Kencana.

Hasbullah (2011). Sistem Pendidikan Nasional Jakarta: Rajawali Pers

Masnur Muslih, (2009). Pembelajaran Berbasis Kompetensi dan Kontekstual. Jakarta: Bumi Aksara.

Ngalim Purwanto. (1997). Prinsip-Prinsip dan Teknik Evaluasi Pengajaran, Bandung: PT. Remaja Rosdakarya

Qodri Azizy. (1995). Pendidikan, Islam, Tradisi dan Modernisasi Menuju Milenium Baru, Jakarta: Logos Wacana Ilmu,

Ramayulis. (2002). Ilmu Pendidikan Islam, Jakarta: Kalam Mulia

Undang-Undang Republik Indonesia No 20 Tahun 2003, Tentang Sistem Pendidikan Nasional (SISDIKNAS). (2003). Bandung: Citra Umbara,

Wina Sanjaya. (2017). Strategi Pembelajaran Berorientasi Standar Proses Pendidikan. Jakarta: Prenada Media Group,

Wina Sanjaya. (2006). Strategi Belajar Mengajar. Jakarta: Kencana Prenada

W.J.S. Porwadarminta. (1999). Kamus Besar Bahasa Indonesia, Jakarta: Balai Pustaka 